\title{
摘葉がナバナ側枝の収量と化学形態別カルシウム含量に及ぼす影響
}

\author{
林田達也 ${ }^{1 *}$ ・尾形武文 ${ }^{2} \cdot$ 浜地勇次 $^{2}$ \\ 1 福岡県農業総合試験場豊前分場 824-0038 福岡県行橋市西泉 2-4-1 \\ 2 福岡県農業総合試験場８18-8549＼cjkstart福岡県筑紫野市大字吉木 587
}

\section{Effects of Defoliation on Lateral Shoot Yield and Calcium Contents in Turnip Rape}

\author{
Tatsuya Hayashida ${ }^{1 *}$, Takefumi Ogata ${ }^{2}$ and Yuji Hamachi ${ }^{2}$ \\ ${ }^{I}$ Buzen Branch, Fukuoka Agricultural Research Center, Yukuhashi, Fukuoka 824-0038 \\ ${ }^{2}$ Fukuoka Agricultural Research Center, Chikushino, Fukuoka 818-8549
}

\begin{abstract}
Summary
To produce turnip rape (Brassica napus L.) with high concentrations of total calcium $(\mathrm{Ca})$ and water-soluble $\mathrm{Ca}$, we investigated the effect of defoliation on the form and levels of $\mathrm{Ca}$ (water-, $1 \mathrm{~N}-\mathrm{NaCl}-, 2 \% \mathrm{CH}_{3} \mathrm{COOH}-$ and $5 \% \mathrm{HCl}$-soluble $\mathrm{Ca}$ ) in the lateral shoots of turnip rape.

By defoliation after pinching in November, the elongation of lateral shoots was inhibited and the yield of lateral shoots was reduced to $84 \sim 91 \%$ of the control without defoliation. Defoliation significantly increased total and water-soluble Ca concentrations in lateral shoots of turnip rape from November to December, but not those after January.
\end{abstract}

Key Words : water-soluble calcium

キーワード : 水溶性カルシウム

\begin{abstract}
緒言
ツケナの一種であるナバナ（Brassica napus L.）は，腋芽 から発生してくる側枝が青果用として，株全体がジュース 用原料として利用されている. ナバナは, シュンギク， ホ ウレンソウなどの葉菜類に比べて, 総カルシウム $(\mathrm{Ca})$ 含 量が高いだけでなく，人体に吸収されやすい水溶性 $\mathrm{Ca}$ 含 量 (原, 1951; Patton・Sutton, 1952; Patton, 1955) も高く, Ca の供給源として優れた作物であるが（林田ら，1999）, 総 $\mathrm{Ca}$ 含量や水溶性 $\mathrm{Ca}$ 含量は収穫時期や生育温度によって変 動することが明らかにされている（林田ら，2003）。

近年, 消費者の健康志向が高まる中で, ナバナの総 $\mathrm{Ca}$ 含 量および水溶性 $\mathrm{Ca}$ 含量に影響を及ぼす栽培上の要因を明 らかにすることは, ナバナの商品価值を一層高めて, その 生産振興を図る上で非常に重要であると考えられる.

ナバナの栽培では, 株の過繁茂を防ぎ, 収穫時の作業性 を高めるために，摘心後に上位の摘葉が行われている．リ ンゴや西洋ナシ等では, 夏季にせん定を行って葉数を制限 すると，果実中の Ca 含量が高まる（Forshey ら，1992；高 辻・青葉，1984）。また，トマトでは，Ca 欠乏による果実の 尻腐れ症の発生が, 摘葉により減少する（佐藤ら， 2004）.
\end{abstract}

2005 年 3 月 16 日 受付. 2005 年 8 月 31 日 受理.

* Corresponding auther. E-mail: hayashid@farc.pref.fukuoka.jp
これらの報告は, ナバナの $\mathrm{Ca}$ 含量が摘葉によってさらに 高められることを示唆している。 しかし，ナバナに拉いて は $\mathrm{Ca}$ 含量に及ぼす摘葉の影響については明らかにされて いない.

そこで, $\mathrm{Ca}$ 供給源としてのナバナの商品価值をさらに高 める目的で, 摘葉がナバナの側枝の収量, 総 $\mathrm{Ca}$ 含量および 化学形態別 $\mathrm{Ca}$ 含量に及ぼす影響を検討した.

\section{材料および方法}

試験は福岡県農業総合試験場豊前分場で行った。ツケナ の一種であるナバナの系統, 京築在来 (Brassica napus L.) を供試した。 2001 年 9 月 17 日に, 園芸培養土（清新産業） を詰めた 10 号ペーパーポット $(4.7 \mathrm{~cm} \times 4.7 \mathrm{~cm} \times 5.0 \mathrm{~cm})$ に 播種し，八ウス内で育苗した。 30 日間の育苗後, 10 月 16 日に露地圃場に定植し，マルチ栽培を行なった．本圃では 元肥として炭酸苦土石灰を $\mathrm{Ca}$ 成分量で $1 \mathrm{a}$ 当たり $4.7 \mathrm{~kg}$, $\mathrm{N} ， \mathrm{P}$ および $\mathrm{K}$ を $1 \mathrm{a}$ 当たりそれぞれ $2.5 ， 1.1$ および $1.8 \mathrm{~kg}$ 施用した。葉数が約 17 枚となった 11 月 7 日に, 新葉 5 枚 を含む主茎上部を除去した，その後直ちに，残りの主菱の 上位から 3 枚扣よび 6 枚の葉を, 葉柄基部を $5 \mathrm{~cm}$ 程度残し て摘除した 2 つ処理区（それぞれ 3 枚摘葉区，6枚摘葉 区とする）と無摘葉区を設けた。 なお，ナバナの栽培では 慣行的に, 摘心後に上位から 3 枚程度の摘葉を実施してい る. 1 区当たり 30 株を供試し， 3 反復の実験を行った. 
11 月 7 日には摘葉前の 6 株の展開葉を葉位別に, 12 月 3 日拉よび 1 月 15 日には，それぞれ処理区の 4 株の展開葉 を主茎と側枝に分けて, 自動葉面積計（林電工株式会社製 AAM-7）で測定した.

各試験区とも 11 月 19 日から 2 月 12 日までの間, 1 次お よび 2 次腋芽から発生した側枝について，基部から 2 葉を 残した長さが $20 \sim 25 \mathrm{~cm}$ に達したものを収穫した. 収穫は 午前中に行い, 収穫本数扔よび生体重を調査した。 また, 収穫物を約 $5 \mathrm{~mm}$ 角に刻んで, $\mathrm{Ca}$ 含量の分析に供した。

$\mathrm{Ca}$ の分析は南出ら（1986）の方法により行った. すなわ ち, 試料（新鮮物約 $10 \mathrm{~g}$ ) に蒸留水 $20 \mathrm{~mL}$ を加え, 水中で 磨砕し, $20^{\circ} \mathrm{C}$ で 1 時間放置後, $3,000 \times \mathrm{g}$ で 10 分間遠心分離 した. 上澄を別容器に移し, 残さに蒸留水 $20 \mathrm{~mL}$ を加えて, よく混ぜ, $20^{\circ} \mathrm{C} て ゙ 1$ 時間放置後, 再び遠心分離した. この 操作をもら一度繰り返した後, 得られた上澄を集めて $100 \mathrm{~mL}$ に定容し, 水溶性 $\mathrm{Ca}$ 画分とした. 残さに $1 \mathrm{~N}-\mathrm{NaCl}$ を加えて同様の分画を行い, 得られた上澄は塩可溶性 Ca画 分とした. 同様に, 残さに $2 \%$ 䣫酸を加えて分画を行い, 酢 酸可溶性 $\mathrm{Ca}$ 画分とした. さらに, 残さに5\%塩酸を加え, 同様な分画を行い, 得られた上澄を塩酸可溶性 $\mathrm{Ca}$ 画分と した. 各画分のサンプルをサンドバス上で乾固し，その後 乾式灰化して，1N 塩酸で $\mathrm{Ca}$ を抽出した. $\mathrm{Ca}$ の定量は各画 分の抽出液に $1,000 \mathrm{ppm}$ の濃度になるように塩化ストロン チウムを加え, 原子吸光法で行った. 総 $\mathrm{Ca}$ 含量はこれら 4 種の化学形態の $\mathrm{Ca}$ 含量の合計值とし, それぞれ新鮮物重 当たりで表した.

\section{結 果}

\section{1. 摘葉がナバナの葉面積の推移および収量に及ぼす影響}

摘葉がナバナの葉面積に及ぼす影響を第 1 表に示した。 摘葉前（11 月 7 日）の 1 株当たりの葉面積は, 主枝で $3,349 \mathrm{~cm}^{2}$, 側枝で $1,330 \mathrm{~cm}^{2}$ であった. 葉面積を葉位別に

第 1 表 摘葉がナバナの葉面積 $\left(\mathrm{cm}^{2} /\right.$ 株 $)$ に及ぼす影響

\begin{tabular}{|c|c|c|c|c|c|c|}
\hline \multirow{2}{*}{ 処理区 } & \multicolumn{2}{|c|}{11 月 7 日 } & \multicolumn{2}{|c|}{12 月 3 日 } & \multicolumn{2}{|c|}{1 月 15 日 } \\
\hline & 主茎 & 側枝 & 主茎 & 側枝 & 主茥 & 側枝 \\
\hline 無摘葉区 & 3,349 & 1,330 & $5,160 \mathrm{c}^{\mathrm{z}}$ & $2,936 \mathrm{a}$ & 564 & $5,229 b$ \\
\hline 3 枚摘葉区 & - & - & $2,149 b$ & $2,954 a$ & 0 & $4,776 \mathrm{~b}$ \\
\hline 6 枚摘葉区 & - & - & $302 \mathrm{a}$ & $2,453 \mathrm{a}$ & 0 & $3,038 \mathrm{a}$ \\
\hline
\end{tabular}

z表中のアルファベットの異文字間には $5 \%$ 水準で有意差あ り（Tukey の検定）
計測した結果から推測すると，3 枚摘葉区と 6 枚摘葉区に 扣ける摘葉直後の主茎の葉面積は, 無摘葉区のそれぞれ 66，26\%程度であった. 12 月 3 日に抢ける 1 株当たりの主 茎の葉面積は, 無摘葉区が $5,160 \mathrm{~cm}^{2}, 3$ 枚摘葉区が $2,149 \mathrm{~cm}^{2}$, 6 枚摘葉区は $302 \mathrm{~cm}^{2}$ であり, 摘葉枚数が多くなるほど小 さかった. 一方，1 株当たりの側枝の葉面積は，処理区間 に有意差は認められなかった。 その後, 主茎の葉はいずれ の処理区とも，1月 15 日までに大部分が枯死した． 1 月 15 日に抢ける 1 株当たりの側枝の葉面積は，6 枚摘葉区で無 摘葉区，3枚摘葉区より小さかった.

摘葉がナバナの側枝の収量, 収穫本数および 1 本当たり 重量に及ぼす影響を第 2 表に示した. $11 〜 12$ 月における 収量および収穫本数は, 処理区間に有意差が認められな かったが，収穫物 1 本当たりの重量では 6 枚摘葉区が無摘 葉区より有意に重かった. $1 \sim 2$ 月に拈ける収量は，無摘 葉区が 1 株当たり $298 \mathrm{~g}, 3$ 枚摘葉区が $246 \mathrm{~g}, 6$ 枚摘葉区が $196 \mathrm{~g}$ であり, 摘葉枚数が多くなるほど有意に低下した。 た，収穫物 1 本当たりの重量は処理区間に有意差が認めら れなかった. $11 〜 2$ 月に抢ける総収量を比較すると, 無摘 葉区が 1 株当たり $439 \mathrm{~g}, 3$ 枚摘葉区が $401 \mathrm{~g}, 6$ 枚摘葉区が $368 \mathrm{~g}$ であり, 6 枚摘葉区は無摘葉区の $84 \%$, 有意に低 かった. 収穫本数も総収量と同様の傾向であった。 これに 対し, 収穫物 1 本当たりの重量は，6枚摘葉区が無摘葉区, 3 枚摘葉区より有意に重かった.

\section{2. 摘葉がナバナの総 $\mathrm{Ca}$ 含量および化学形態別 Ca 含量に 及ぼす影響}

摘葉がナバナの総 $\mathrm{Ca}$ 含量に及ぼす影響を第 1 図に示し た. ナバナの総 $\mathrm{Ca}$ 含量は，処理区間で有意差が認められ た. すなわち, 11 月 19 日に抢ける 6 枚摘葉区の総 $\mathrm{Ca}$ 含量 は $1.35 \mathrm{mg} \cdot \mathrm{g}^{-1} \mathrm{FW}$ であり, 無摘葉区の $0.65 \mathrm{mg} ・ \mathrm{~g}^{-1} \mathrm{FW}$ よ り有意に高かった. また, 3 枚摘葉区の総 $\mathrm{Ca}$ 含量も $0.95 \mathrm{mg}$ ・ $\mathrm{g}^{-1} \mathrm{FW}$ であり, 無摘葉区より高い傾向が認められた。 11 月 28 日と 12 月 12 日に拈ける 6 枚摘葉区の総 $\mathrm{Ca}$ 含量は 1.08 と $1.17 \mathrm{mg} \cdot \mathrm{g}^{-1} \mathrm{FW}$ であり，無摘葉区の 0.60 と $0.76 \mathrm{mg} \cdot \mathrm{g}^{-1}$ $\mathrm{FW}$ より有意に高かった。 しかし，1月 8 日以降になると， 6 枚摘葉区と無摘葉区との間に有意差は認められなかっ た. 3 枚摘葉区と 6 枚摘葉区の総 $\mathrm{Ca}$ 含量を比較すると, 11 月 28 日と 12 月 12 日に拈いて, 後者は前者より有意に高 く，打よそ $1.3 〜 1.4$ 倍あった.

摘葉がナバナの水溶性 $\mathrm{Ca}$ 含量に及ぼす影響を第 2 図に 示した. 水溶性 $\mathrm{Ca}$ 含量は総 $\mathrm{Ca}$ 含量と同様に, 12 月までは

第 2 表 摘葉がナバナの収量, 収穫本数および 1 本当たり重量に及ぼす影響

\begin{tabular}{|c|c|c|c|c|c|c|c|c|c|}
\hline \multirow[t]{2}{*}{ 処理区 } & \multicolumn{3}{|c|}{ 収量（g/株） } & \multicolumn{3}{|c|}{ 収穫本数（本 / 株） } & \multicolumn{3}{|c|}{1 本当たり重量（g） } \\
\hline & $11 \sim 12$ 月 & $1 \sim 2$ 月 & 合計 & $11 \sim 12$ 月 & $1 \sim 2$ 月 & 合計 & $11 \sim 12$ 月 & $1 \sim 2$ 月 & 平均 \\
\hline 無摘葉区 & $141 \mathrm{a}^{\mathrm{z}}$ & $298 \mathrm{c}$ & $439 b$ & $11.7 \mathrm{a}$ & $16.7 \mathrm{~b}$ & $28.4 b$ & $12.0 \mathrm{a}$ & $17.8 \mathrm{a}$ & $15.4 \mathrm{a}$ \\
\hline 3 枚摘葉区 & $155 \mathrm{a}$ & $246 b$ & $401 \mathrm{ab}$ & $11.4 \mathrm{a}$ & $13.7 \mathrm{ab}$ & $25.1 \mathrm{ab}$ & $13.5 \mathrm{ab}$ & $17.9 \mathrm{a}$ & $15.9 \mathrm{a}$ \\
\hline 6 枚摘葉区 & $172 \mathrm{a}$ & $196 \mathrm{a}$ & $368 \mathrm{a}$ & $10.6 \mathrm{a}$ & $10.6 \mathrm{a}$ & $21.2 \mathrm{a}$ & $16.2 \mathrm{~b}$ & $18.4 \mathrm{a}$ & $17.3 \mathrm{~b}$ \\
\hline
\end{tabular}

z表中のアルファベットの異文字間には 5\%水準で有意差あり（Tukey の検定） 


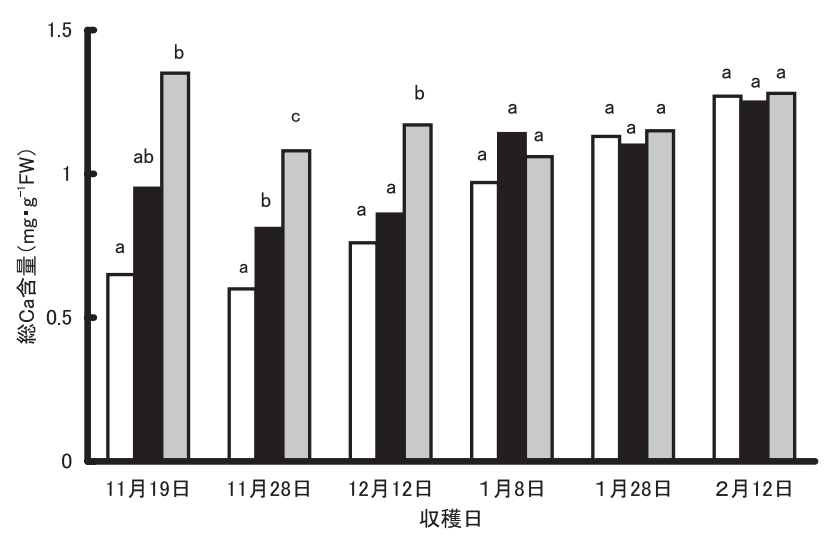

第 1 図摘葉がナバナの総 $\mathrm{Ca}$ 含量に及ぼす影響 図中のアルファベット異文字間には $5 \%$ 水準で有意差あ り (Tukey の検定)

$\square$ 無摘葉区 $\square 3$ 枚摘葉区 $\square 6$ 枚摘葉区

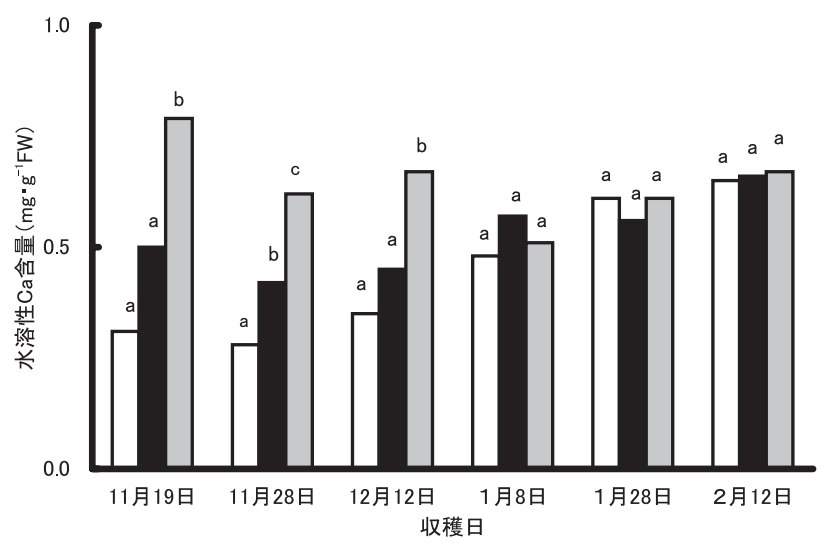

第 2 図摘葉がナバナの水溶性 $\mathrm{Ca}$ 含量に及ぼす影響 図中のアルファベット異文字間には5\%水準で有意差あ り (Tukey の検定)

$\square$ 無摘葉区 $\square 3$ 枚摘葉区 $\square 6$ 枚摘葉区

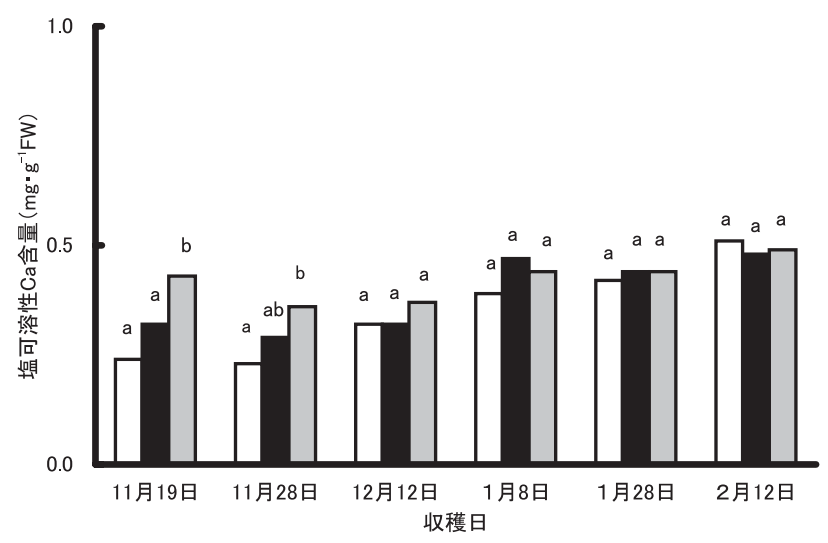

第 3 図摘葉がナバナの塩可溶性 $\mathrm{Ca}$ 含量に及ぼす影響 図中のアルファベット異文字間には5\%レベルで有意差 あり（Tukey の検定）

$\square$ 無摘葉区 $\quad 3$ 枚摘葉区 $\square 6$ 枚摘葉区
摘葉によって高くなった. すなわち，11月 19 日〜 12 月 12 日に打ける 6 枚摘葉区の水溶性 $\mathrm{Ca}$ 含量は $0.62 \sim 0.79 \mathrm{mg}$ ・ $\mathrm{g}^{-1} \mathrm{FW}$ であり, 無摘葉区の $0.28 \sim 0.35 \mathrm{mg} \cdot \mathrm{g}^{-1} \mathrm{FW}, 3$ 枚摘 葉区の $0.42 \sim 0.50 \mathrm{mg} \cdot \mathrm{g}^{-1} \mathrm{FW}$ より有意に高かった。 しか し, 1 月 8 日以降では, 処理区間に有意差が認められなかっ た. 総 $\mathrm{Ca}$ 含量に対する水溶性 $\mathrm{Ca}$ 含量の比率は, 11 月 19 日では 6 枚摘葉区が $58.4 \%$ であり，無摘葉区の $47.6 \%$ より 有意に高かった。この比率は 11 月 28 日拉よび 12 月 12 日 でも同様の傾向にあったが，1月 8 日以降には処理区間に 有意差が認められなかった. 3 枚摘葉区と 6 枚摘葉区に拈 ける総 $\mathrm{Ca}$ 含量に占める水溶性 $\mathrm{Ca}$ 含量の比率には, 有意差 が認められなかった (データ省略).

摘葉がナバナの塩可溶性 $\mathrm{Ca}$ 含量に及ぼす影響を第 3 図 に示した. 塩可溶性 $\mathrm{Ca}$ 含量は水溶性 $\mathrm{Ca}$ 含量と同様に, 摘 葉によって高まる傾向が認められた，すなわち，塩可溶性 $\mathrm{Ca}$ 含量は, 11 月 19 日扣よび 11 月 28 日には 6 枚摘葉区が 無摘葉区より有意に高かった. 3 枚摘葉区と 6 枚摘葉区の 塩可溶性 $\mathrm{Ca}$ 含量を比較すると, 11 月 19 日には後者の方が 有意に高かったが，12月 12 日以降は有意差は認められな かった。

酢酸可溶性扔よび塩酸可溶性 $\mathrm{Ca}$ 含量は，いずれの区と も $0.10 \mathrm{mg} \cdot \mathrm{g}^{-1} \mathrm{FW}$ 以下で推移し, 処理区間に有意差が認め られなかった（データ省略）.

四つの化学形態別 $\mathrm{Ca}$ 含量を比較すると, 水溶性 $\mathrm{Ca}$ 含量 がいずれの収穫時期や処理区ともに最も高く, 次いで塩可 溶性 $\mathrm{Ca}$ 含量, 酢酸可溶性 $\mathrm{Ca}$ 含量の順であった. また, 水 溶性 $\mathrm{Ca}$ 含量と塩可溶性 $\mathrm{Ca}$ 含量で総 $\mathrm{Ca}$ 含量の $85 \sim 92 \%$ を占めた。

\section{考察}

本研究では，ナバナについて，本葉 17 枚展開時（11 月 7 日）に上位から 5 枚の葉を含めて摘心し，さらに上位か ら 3 枚ないし 6 枚を摘葉して，その後に発生する側枝の収 量および Ca 含量がどのように推移するのかを検討した.

その結果，小田原ら（1991）の報告にもあるように，摘 葉はナバナの側枝の伸長に大きな影響を及ぼし，1〜2月 に拈ける側枝の収量は, 摘葉枚数が多くなるほど少なかっ た. このように, ナバナ栽培に抢ける摘心時の摘葉は収量 の低下をもたらすことが明らかとなった。

次に, 摘葉がナバナ側枝の総 $\mathrm{Ca}$ 含量および化学形態別 $\mathrm{Ca}$ 含量に及ぼす影響について，収穫期間を通してみると， 無摘葉区では，11〜 12 月に打ける総 $\mathrm{Ca}$ 含量が低く, 1 月 以降, 落葉による主茎の葉面積の減少とともに総 $\mathrm{Ca}$ 含量 が高くなった。 これに対して，6 枚摘葉区では収穫期間を 通して総 $\mathrm{Ca}$ 含量が高い水準で維持された．また， $11 〜 12$ 月に拈ける収穫物の総 $\mathrm{Ca}$ 含量は, 摘葉枚数が多くなるほ ぞ高い傾向にあったが，これは摘葉によって主茎の葉の生 長が抑えられ，その影響で側枝に $\mathrm{Ca}$ がより多く蓄積した ためと推察される. 
水溶性 $\mathrm{Ca}$ はイオン化物, 無機塩および有機酸塩として 植物体中に存在する (小西・葛西, 1963; 太田ら, 1970). 植 物の根からイオンとして吸収された $\mathrm{Ca}$ は，植物体内では 主に有機酸と結合して移動する（三井，1970）。また，陳・ 上本（1976）は，トマト抢よび八クサイで，水溶性 Ca が 植物の器官を移動していることを示唆している. 本研究で は, 摘葉によりナバナの側枝の総 $\mathrm{Ca}$ 含量が高くなるとと もに水溶性 $\mathrm{Ca}$ 含量も高まった. これらのことから, ナバ ナを摘葉した場合, 水溶性 $\mathrm{Ca}$ が側枝により多く転流し, 蓄 積したものと推察される。このように, 摘葉は人体に吸収 されやすい水溶性 $\mathrm{Ca}$ 含量を高める上で有効であることが 示された.

塩可溶性 $\mathrm{Ca}$ はその大部分が細胞壁を構成する食物繊維 であるペクチンと結合しているため（小西・葛西，1963； 太田ら，1970)，人体に吸収されにくい（奥，1995）。摘葉 は, 11 月 28 日までのナバナに打ける塩可溶性 $\mathrm{Ca}$ 含量を高 めたが，その増加程度は水溶性 $\mathrm{Ca}$ 含量より小さかった

ナバナの栽培では，本研究の 3 枚摘葉区と同じような摘 葉を一般に実施している. この摘葉は株の過繁茂を防ぎ, 収穫時の作業性を高める点で重要な作業となっている。 し かしナバナを摘葉した場合, 6 枚摘葉区で無摘葉区の $16 \%$, 3 枚摘葉区の $9 \%$ 収量が減少するなど減収となることから, 収量をいかに向上させるかが今後の重要な課題である.ナ バナは密植により, 収量が高まることが報告されており(小 田原ら，1990), 今後は栽植密度等の検討により高い総 $\mathrm{Ca}$ 含量や水溶性 $\mathrm{Ca}$ 含量を維持させながら, 収量を向上させ る必要がある.

一方，ナバナの品質は，福岡県では 1 本当たりの重量で 格付けされて打り，10 $\mathrm{g}$ 以上のものが秀品として出荷され ている. 本試験に打ける 6 枚摘葉区では, $11 \sim 12$ 月の 1 本当たりの重量が重く, 無摘葉区, 3 枚摘葉区に比べ規格 面での品質が向上した。 このように，摘葉によって栽培期 間を通して，均一で高 $\mathrm{Ca}$ 含量を有する高品質なナバナを 出荷できることが明らかになった。 また， 八クサイでは被 覆硝酸石灰を全量元肥で施用することによって Ca 含量が 高まるとの報告もあり（関，1995）, 石灰資材の施用法等を 検討して, 総 $\mathrm{Ca}$ 含量をさらに高めることも可能と考えら れる.

以上のように,ナバナでは 11 月上旬の摘心時に摘葉する ことによって, 収穫物の総 $\mathrm{Ca}$ 执よび水溶性 $\mathrm{Ca}$ の含量が高 くなることが明らかとなった，近年，農産物の機能性に対 する消費者の関心が高まる中で, 摘葉により $\mathrm{Ca}$ 供給源と してのナバナの有用性を高めることは, ナバナの生産振興 を図っていく上で, 重要であると考えられる.

\section{摘 要}

$\mathrm{Ca}$ 含量の高いナバナを生産する目的で, 摘葉がナバナの 側枝の収量, 総 $\mathrm{Ca}$ 含量および化学形態別 $\mathrm{Ca}$ 含量に及ぼす 影響を検討した.
11 月上旬の摘心時の摘葉により, 側枝の伸長が抑兄られ, 生育期間中の 3 枚摘葉区および 6 枚摘葉区に括ける総収量 は，無摘葉区と比較して，それぞれ $91 \% ， 84 \%$ と低下した。 その一方で，11〜 12 月に打る総 $\mathrm{Ca}$ 含量と水溶性 $\mathrm{Ca}$ 含 量は，摘葉枚数が多くなるほど高くなった. 1 な 月にお ける総 $\mathrm{Ca}$ 含量と水溶性 $\mathrm{Ca}$ 含量は, 処理区間に有意差がな かった.

以上のことから, ナバナの収量は摘葉により低下するも のの, 総 $\mathrm{Ca}$ 含量や水溶性 $\mathrm{Ca}$ 含量が高まり, 6 枚摘葉区で は収穫期間を通して, 高い水準で $\mathrm{Ca}$ 含量を維持できるこ とが示唆された。

\section{引用文献}

陳 文孝・上本俊平. 1976. そ菜のカルシウム吸収に関す る研究. (第 1 報) そ菜の異なった生長相に和けるカル シウム吸収とその生理的意義. 園学雑. 45: 33-42.

Forshey, G. G., D. C. Elfving and R. L. Stebbins. 1992. Training and prunning apple and pear trees. p. 62. Alexandria, Virginia.

原登志子. 1951. Calcium の利用に関する実験的研究一特に 骨粉の利用について。栄養学雑誌. 9: 1-6.

林田達也・柴戸靖志・浜地勇次. 1999. ツケナに扣けるカル シウムの形態別含量およびその品種間差異. 園学雑. 68: 897-899.

林田達也・柴戸靖志・尾形武文・浜地勇次. 2003。収穫時 期および生育温度によるツケナの化学形態別カルシウ ム含量の変動. 園学雑. 72: 169-174.

小西茂毅・葛西善三郎. 1963. タバコ葉の Ageingにともな らカルシウムの代謝.（その1）生育各期に吸収された ${ }^{45} \mathrm{Ca}$ の形態変化. 土肥誌. 34: 67-70.

南出隆久・後藤昌弘・岩田 隆. 1986. 青果物に括ける力 ルシウム $(\mathrm{Ca})$ の存在形態の相違と収穫後の变化. 園 学雑. 54: 507-513.

三井進午. 1970 . 最新土壤 - 肥料植物栄養辞典. p. 200. 博 友社. 東京.

小田原孝治・矢野雅彦・尾形武文. 1990. ナバナの安定栽 培技術（第 1 報）播種期, 栽植密度及び施肥法と収量. 福岡農総試研報. 10: 27-30.

小田原孝治・矢野雅彦・松江勇次. 1991. ナバナの安定栽 培技術（第 2 報）側枝の生育に及ぼす気温ならびに摘 心，摘葉処理の影響. 福岡農総試研報. 11:35-38.

奥 恒行. 1995. 食事栄養成分の消化吸収への影響. p. 113119. 印南 敏・桐山修八編著. 食物繊維. 第一出版. 東京.

太田安定・山本和子・出口正夫. 1970. カルシウム供給量, 葉位, 個体の生育段階の違いが水稲生葉内のカルシウ ムの化学形態別分布におよぼす影響. 土肥誌. 41:1926.

Patton, M. B. and T. S. Sutton. 1952. The utilization of calcium 
from lactate, gluconate, sulfate, and cabonate salts by young college women. J. Nutr. 48: 443-452.

Patton, M. B. 1955. Further experiments on the utilization of calcium from salts by college women. J. Nutr. 55: 519-526. 佐藤 卓 - 森田健太郎 - 池田英男 - 古川 - - 飯村裕史 小湊正幸. 2004. 摘葉がトマトの尻腐れ果発生に及ぼ す影響. 園学研. 3:183-186.
関稔. 1995. 被覆肥料による全量元肥方式一露地野菜. p. 92 の 24-92の 32. 農業技術体系土壤施肥編 6. 農山 漁村文化協会. 東京.

高辻豊二・青葉幸二. 1984. ナシの生理障害に関する研究 (第 5 報) 新梢管理と袋掛けが硬化障害発生に及ぼす影 響. 園学雑. 64 (別 1): 118-119. 